Ks. Marek Podgórski

Tarnów

\title{
TROSKA O ŚWIADECTWO ŻYCIA KAPŁAŃSKIEGO W DOKUMENTACH SYNODÓW DIECEZJI TARNOWSKIEJ
}

Kodeks prawa kanonicznego, promulgowany przez papieża Benedykta XV, polecał, aby w każdej diecezji - przynajmniej co dziesięć lat - miał miejsce synod diecezjalny. W Polsce międzywojennej odbyło się czternaście synodów diecezjalnych i jeden synod plenarny. W 1928 roku swego pierwszego syno$\mathrm{du}$ - po ponad stu latach od erygowania - doczekała się też diecezja tarnowska. Ówczesny biskup tarnowski Leon Wałęga od początku pasterskiej posługi, czyli od roku 1901, dostrzegał konieczność przeprowadzenia synodu diecezjalnego, w praktyce jednak nie dążył do jego zwołania i uczynił to, jak sam zresztą przyznał, dopiero pod naciskiem Stolicy Apostolskiej ${ }^{1}$.

W kwietniu 1927 roku biskup tarnowski ogłosił zwołanie synodu diecezjalnego, stawiając przed nim następujące cele: uzgodnienie dotychczas obowiązującego w diecezji prawa $\mathrm{z}$ Kodeksem prawa kanonicznego oraz uzupełnienie diecezjalnego prawa nowymi przepisami. Synod odbył się w Tarnowie, w sierpniu 1928 roku, a zostało na niego zaproszonych 151 księży (czyli około 31 proc. ogółu duchowieństwa diecezjalnego). Uchwalono łącznie 275 statutów, ponadto dołączono do nich 19 dodatków, zwłaszcza szczegółowych instrukcji, dotyczących różnych kwestii duszpasterskich lub administracyjnych. Statuty synodalne zaczęły obowiązywać od 1 stycznia 1929 roku².

Zgodnie ze wspomnianymi poleceniami Kodeksu prawa kanonicznego w lipcu 1938 roku odbył się II synod, przeprowadzony przez biskupa tarnowskiego

1 B. Kumor, Diecezja tarnowska. Dzieje ustroju i organizacji 1786-1985, Kraków 1985, s. 363-367; Pierwszy Synod Diecezji Tarnowskiej. 1928, Tarnów 1928, s. 22 [dalej: I Synod...].

2 B. Kumor, Diecezja tarnowska ..., dz. cyt., s. 367-369. 
Franciszka Lisowskiego. Od poprzedniego synodu diecezjalnego minęło już bowiem dziesięć lat, a ponadto weszły w życie uchwały I Polskiego Synodu Plenarnego z 1936 roku. Akta II Synodu Diecezji Tarnowskiej nie zostały jednak opublikowane i nigdy nie weszły w życie. W późniejszych latach dokumentacja synodu w dużej mierze została rozproszona, jednak w ostatnim czasie dzięki staraniom ks. dr. Roberta Kantora dokonano uporządkowania statutów tegoż synodu ${ }^{3}$.

Po II wojnie światowej biskup tarnowski Jan Stepa zwołał III Synod diecezjalny, który odbył się w lipcu 1948 roku. Do udziału w nim powołano 160 księży. Na III Synodzie uchwalono 277 statutów, z czego 101 poświęcono zagadnieniom karności kościelnej. Dołączono do niego osiem instrukcji synodalnych. Pomimo radykalnie zmienionej w Polsce sytuacji społeczno-politycznej III Synod w zasadzie powielał wcześniejsze synodalne postanowienia i nie znalazło się w nim zbyt wiele nowych rozwiązań4.

Ostatni jak dotąd synod diecezji tarnowskiej miał miejsce w latach 19811986, podczas pasterskiej posługi biskupa tarnowskiego Jerzego Ablewicza. Ze wszystkich dotychczasowych był to synod trwający najdłużej i w liczbie statutów (aż 749) najbardziej monumentalny. W porównaniu do poprzednich synodów różnił się od nich bardzo wyraźnie, praktycznie w każdym wymiarze. W przebieg IV Synodu po raz pierwszy zaangażowano wiernych świeckich, podjęte przez ojców synodalnych prace były bardzo dokładne, wręcz drobiazgowe, a sam synod trwał kilka lat. Dokonano wówczas przeglądu wszystkich aspektów funkcjonowania diecezji w nowych warunkach, mając zwłaszcza na uwadze postanowienia Soboru Watykańskiego II. Po promulgowaniu w 1983 roku nowego Kodeksu prawa kanonicznego przez papieża Jana Pawła II, również IV Synod Diecezji Tarnowskiej w pełni dostosował się do postanowień tegoż dokumentu. Należy także podkreślić, iż IV Synod stanowił bardzo istotne przygotowanie do jubileuszu 200 rocznicy powstania diecezji ${ }^{5}$.

3 R. Kantor, Synod w przededniu wojny. II Synod Diecezji Tarnowskiej - historia i rekonstrukcja statutów, Tarnów 2017; B. Kumor, Diecezja tarnowska..., dz. cyt., s. 369-371.

4 B. Kumor, Diecezja tarnowska ..., dz. cyt., s. 371-373; Trzeci Synod Diecezji Tarnowskiej. 1948, „Currenda. Pismo Urzędowe Diecezji Tarnowskiej” (1957) nr 6-7 [dalej: III Synod...].

5 IV Synod Diecezji Tarnowskiej, Tarnów 1990 [dalej: IV Synod...]; B. Kumor, Diecezja tarnowska ..., dz. cyt., s. 373-377; B. Olejnik, Ad imaginem Ecclesiae universa- 
Wszystkie synody diecezji tarnowskiej podjęły i przepracowały, a następnie odpowiednio skodyfikowały zagadnienia dotyczące troski o godne życie kapłańskie, w różnych jego aspektach. Wskazania synodów, a zatem zawarte w statutach wszelkie nakazy, zakazy oraz zalecenia, miały w założeniu dopomóc duchownym diecezji tarnowskiej w jak najpełniejszej realizacji powołania, w służbie Bogu i ludziom. Wydaje się, iż ojcowie synodalni wszystkich dotychczasowych synodów bardzo dobrze i rzetelnie zrealizowali wspomniane zamierzenie. Obecnie - po wielu latach - nadal zauważamy głębię i mądrość zawartą w synodalnych statutach.

Poniżej przedstawiono najważniejsze aspekty życia duchownych diecezji tarnowskiej, które zostały podjęte, opracowane i skodyfikowane przez kolejne synody diecezji tarnowskiej.

\section{Życie ascetyczne}

I Synod podał jako podstawę duchowości kapłańskiej obszerną odezwę papieża Piusa X do duchowieństwa Haerent animo z sierpnia 1908 roku. Została ona zresztą umieszczona jako dodatek do tegoż synodu. Pośród codziennych praktyk pobożnych kapłana diecezji tarnowskiej I Synod wymienił: godne i pobożne celebrowanie Najświętszej Ofiary, brewiarz, rozmyślanie i czytanie duchowne, rachunek sumienia, adorację Najświętszego Sakramentu i nabożeństwo do Najświętszej Maryi Panny. Ponadto przynajmniej raz na dwa tygodnie przystępowanie do sakramentu pokuty i przynajmniej raz na dwa lata trzydniowe rekolekcje. Przypomniano wyraźnie konieczność troski o pogłębienie wiedzy teologicznej i pomnażanie kapłańskiej biblioteki. Została też zalecona praktyka comiesięcznych, prywatnych, jednodniowych rekolekcji. Według I Synodu kapłana winny wyróżniać następujące cnoty, cechy i przymioty: nienawiść grzechu, gorliwość o chwałę Bożą i o zbawienie dusz, dziewicza czystość, łagodność, uprzejmość (lecz nie pobłażliwość wobec występków), miłosierdzie, wstrzemięźliwość, trzeźwość, umiarkowanie.

II Synod oraz III Synod w części drugiej („O karności kościelnej”), przypominając o obowiązkach duchowieństwa, powtarzały dokładnie zapisy I Synodu, po raz kolejny powołując się na wspomnianą wyżej odezwę papieża

lis. Analiza historyczno-prawna struktury i organizacji IV Synodu Diecezji Tarnowskiej $w$ trzydziestolecie zakończenia, Tarnów 2016, s. 46-47, 101-103. 
Piusa X. Uwypuklały również konieczność dokładnej znajomości Pisma Świętego, nieodzownej w posłudze duszpasterskiej.

IV Synod w rozdziale II („Duchowieństwo diecezjalne”) wspomina o „swoistym stylu świętości kapłańskiej” diecezji tarnowskiej. Jako źródła uświęcenia i praktyki ascetyczne synod polecał: godne i pobożne sprawowanie mszy świętej, pilne odmawianie brewiarza, rozmyślanie, nawiedzenie Najświętszego Sakramentu, lekturę Pisma Świętego i dzieł ascetycznych, modlitwę różańcową, rachunek sumienia, sakrament pokuty (,w miarę możliwości co dwa tygodnie i u jednego spowiednika"), udział w okresowych dniach skupienia, trzydniowe rekolekcje zamknięte raz do roku. Kapłani zostali wezwani do dzielenia się dobrami materialnymi z osobami potrzebującymi, w tym do świadczenia na cele charytatywne.

Osobny statut (394) poświęcono kwestii trzeźwości, co uzasadniono słusznie „społecznym zagrożeniem alkoholizmem” - w peerelowskiej rzeczywistości lat 80. alkoholizm był plagą totalną. Przygnębiająca sytuacja społeczna spowodowała, iż IV Synod wezwał kapłanów, by byli przykładem trzeźwego stylu życia wobec osób świeckich oraz aby podtrzymali w diecezji zwyczaj niepodawania żadnych napojów alkoholowych na uroczystościach kościelnych czy spotkaniach kapłańskich ${ }^{6}$.

\section{Strój duchowny}

Wszystkie synody podjęły i rozważyły to ważne dla kapłańskiej tożsamości zagadnienie, przedstawiając szczegółowe przepisy, które miały wskazać duchownym, jak odpowiednio używać szatę duchowną.

I Synod nakazał, aby kapłani nosili stale sutannę czarną, czystą i całą, natomiast okrycie na sutannę miało być ogólnie barwy ciemnej. Podczas podróży dalszej i dłuższej - duchowni mogli zakładać krótszą czarną suknię, oczywiście z koloratką. W czasie pobytu poza Polską dopuszczalne było stosowanie się do miejscowych zasad dotyczących stroju duchownego, co w praktyce oznaczało

${ }^{6}$ R. Kantor, Drugi Synod Diecezji Tarnowskiej o prawach i obowiazkach duchownych. Próba rekonstrukcji nieopublikowanych statutów synodalnych, [w:] Dzieje Diecezji Tarnowskiej, t. 2: Instytucje i wydarzenia, red. A. Gąsior, J. Królikowski, Tarnów 2012, s. 133-146; R. Kantor, Synod w przededniu ..., dz. cyt., s. 98; I Synod ..., s. 65-66, 127-146; III Synod ..., s. 349-350; IV Synod ..., s. 189-190. 
rezygnację z sutanny. Przypomniano przy tej okazji o konieczności zachowania tonsury (w oryginale - tonzury).

II Synod i III Synod zasadniczo powtórzyły wcześniejsze postanowienia dotyczące sukni duchownej - miała ona być czarna, czysta i cała, a kapłan miał w niej stale występować. Wspomniano również o konieczności posiadania tonsury i koloratki. Podczas podroży czy pracy (fizycznej) dozwolona była krótsza suknia duchowna, niekoniecznie czarna, lecz ogólnie ciemna. Natomiast wierzchnie okrycie sutanny nie powinno zaskakiwać ani kolorem, ani krojem, ani zaniedbaniem schludności. Stroju świeckiego kapłan nie mógł używać bez pozwolenia ordynariusza, a rządcy kościołów nie powinni byli dopuszczać do ołtarza kapłanów bez sutanny. Poza granicami kraju można było jednak stosować miejscowe zwyczaje.

Kodeks prawa kanonicznego z roku 1983 o stroju duchownym wspomina bardzo krótko i ogólnikowo w kan. 284, stwierdzając, iż „duchowni powinni nosić odpowiedni strój kościelny, według przepisów wydanych przez Konferencję Episkopatu, a także zwyczajów miejscowych, zgodnych z przepisami prawa".

IV Synod określił, iż strój duchowny jest zewnętrznym znakiem wartości duchowych i eschatologicznych, stąd też polecił kapłanom podtrzymanie zwyczaju noszenia sutanny, wyraźnie nakazując jej noszenie podczas pełnienia czynności liturgicznych, w kancelarii, na katechezie, w czasie uroczystości religijnych i urzędowych wizyt. Za strój duchowny został uznany także ciemny garnitur z koloratką. Synod zezwolił na noszenie stroju świeckiego w niektórych okolicznościach, takich jak praca fizyczna, uciążliwe podróże, pobyt w miejscach turystycznych, wczasowych i kuracyjnych oraz „w innych wyjątkowych sytuacjach”. Ponieważ ocena wyjątkowości owych sytuacji należała zapewne do samego zainteresowanego, stąd też interpretacja mogła być nader szeroka ${ }^{7}$.

\section{Relacje z osobami świeckimi}

I Synod nakazał, aby w codziennym życiu kapłańskim przejawiała się powaga, umiarkowanie i pobożność. Zarówno I Synod, jak i Synody II i III przykazały duchownym powstrzymanie się od odwiedzania i przyjmowania kobiet,

7 R. Kantor, Synod w przededniu..., dz. cyt., s. 102; Kodeks Prawa Kanonicznego, Poznań 1984, s. 139 [dalej: KPK]; I Synod..., s. 67; III Synod..., s. 352; IV Synod..., s. $190-191$. 
zwłaszcza młodszych, jak również odbywania z nimi wspólnych przechadzek, wycieczek i ogólnie unikania towarzystwa niewiast, przy czym nawet ich pobożność czy istniejące pokrewieństwo nie stanowiły tutaj wystarczającego usprawiedliwienia. Ponadto odwiedzanie rodzin, w których były młode niewiasty, było wprawdzie dopuszczalne, lecz niewskazane - należało takie rodziny nawiedzać rzadko.

I Synod stwierdzał, że do służby kościelnej (kościelni, zakrystianie, organiści, grabarze) należało najmować ludzi odpowiednich, pobożnych, zamiłowanych w porządku i trzeźwych. Kapłan w relacjach z nimi miał obowiązek postępować uprzejmie, a nawet wyrozumiale oraz z dbałością o odpowiednie utrzymanie i wynagrodzenie służby. II Synod oraz III Synod niemal dokładnie powtórzyły te postanowienia.

W IV Synodzie zamiast określenia „służba kościelna” użyto, zgodnie z duchem epoki, bardziej demokratycznego sformułowania ,pracownicy parafialni”. Prawodawca synodalny nakazał, aby pracownikami parafialnymi byli ludzie posiadający nie tylko niezbędne kwalifikacje zawodowe, ale również autentycznie religijni, uczciwi, z zamiłowaniem do pracy i porządku, psychicznie zdrowi oraz pozostający „poza podejrzeniem o uleganie skłonności do pijaństwa”. $\mathrm{W}$ relacjach z pracownikami kapłan winien zachowywać się wyrozumiale, z życzliwością i uprzejmością.

Obok pracowników czy służby kościelnej istniała również służba domowa (plebańska). I Synod wskazywał, że do służby domowej wolno przyjmować jedynie osoby prawdziwie pobożne, trzeźwe, spokojne i starsze. Kobiety przyjęte do służby kapłan miał traktować uprzejmie, lecz „,zawsze z powagą ojcowską", nie dopuszczając równocześnie do najmniejszej poufałości czy też np. do zasiadania przy wspólnym stole lub wspólnych przechadzek albo wprost do „mieszania się w sprawy i zarząd” parafii. Według postanowień III Synodu do posług domowych (czyli służby plebańskiej) można było przyjmować kobiety o dobrej opinii, pobożne i co istotne - po ukończonym czterdziestym roku życia. IV Synod w statutach 718 i 719 przytoczył zasady dotyczące gospodyń plebańskich, nakazując duchownym godne traktowanie tych osób, a także „pamięć w modlitwie” po ich śmierci.

Prawodawca synodalny trzech pierwszych synodów zakazał stałego przebywania na plebanii osób z rodziny kapłana, jeżeli w tej kwestii nie zostało wydane specjalne zezwolenie ordynariusza. Wśród tychże osób wymieniono młode krewniaczki lub ogólnie krewnych z dziećmi. Kapłan został zobowiązany 
do zachowania dystansu wobec udziału w tłumnych przyjęciach, jeżeli jednak miał brać w nich udział, to powinien zachować powagę i unikać wolniejszych żartów, a nawet hałaśliwych rozmów. Ponadto na III Synodzie ogólnie zabroniono odwiedzania ludzi niereligijnych lub podejrzanych. W statucie 33 III Synodu zostało wprost nakazane, by kapłan nie pokazywał się publicznie brudny i nieogolony.

I Synod zabronił kapłanom podejmowania się leczenia bliźnich, zezwolił jednak na udzielanie im porad dotyczących np. udzielania pierwszej pomocy czy codziennej higieny, oczywiście przypominając duchownym, aby nie przyjmowali za to wynagrodzenia. Podobnie stwierdzały statuty II i III Synodu.

W sprawach aktywności społecznej i politycznej I Synod zezwolił na przyjęcie przez kapłana mandatu członka rady gminnej, szkolnej lub powiatowej, a nawet sędziego polubownego, jednakże przestrzegał przed ubieganiem się o te funkcje. Kwestią rozstrzygającą było jednak zawsze dobro Kościoła, stąd zakaz przynależności do stronnictw politycznych, które w sprawach wiary zajmowały stanowisko wrogie, chwiejne lub niejasne. W sytuacji, gdy kapłan został pozwany przed sąd świecki albo sam miał zamiar kogokolwiek pozwać, był zobowiązany powiadomić o tym Kurię Biskupią. W statutach II i III Synodu powtórzone zostały owe nakazy.

IV Synod apelował, aby kapłani utrzymywali łączność z wiernymi świeckimi, także poprzez osobiste spotkania, w celu poznania ich sposobu myślenia i zagadnień codziennego życia. W nawiązaniu do kan. 278 Kodeksu prawa kanonicznego zabroniono duchownym udziału w partiach politycznych czy kierowania związkami zawodowymi bez zgody kompetentnej władzy kościelnej. Zakazano też jawnej lub ukrytej współpracy z przeciwnikami Kościoła. Wspomniano ogólnie o konieczności podejmowania działań duszpasterskich dla ożywienia świadomości społecznej i narodowej. W ten zawoalowany sposób IV Synod (trwający przecież podczas ponurych lat stanu wojennego i bezpośrednio po nim) przekazał jasny komunikat, że ksiądz diecezji tarnowskiej roztropnie powinien jednak zaangażować się po stronie narodu, pozbawionego przez ówczesną władzę podstawowych praw.

W statucie 420 zaznaczono, iż obecność pośród wiernych „powinna być budująca i mieć charakter duszpasterski”. W kolejnym statucie wspomniano również o konieczności prezentowania przez duchownego wysokiej kultury osobistej - w tym kultury wypowiedzi, o stosownym do okoliczności stroju, odpowiednim zachowaniu przy stole, zachowaniu punktualności, odpowiedzialnej 
jeździe samochodem, kultury korespondencji i innych. Ponadto zwrócono uwagę, aby kapłani bezwzględnie unikali rozrywek czy też imprez „,nie licujących ze stanem duchownym". W tym kontekście wymieniono następujące: tańce, zabawy, nieodpowiednie widowiska, nieodpowiednie zachowania towarzyskie $\mathrm{i}$ inne. Na zakończenie stwierdzono, iż w kontaktach z każdym człowiekiem nieodzowny jest szacunek, natomiast należy wystrzegać się zarówno wyniosłości, jak też zbytniej poufałości. Wspomniane wyżej postanowienia statutów z jednej strony były bardzo konkretne (np. jazda samochodem - jednak z niewiadomych przyczyn nie wymieniono innych środków lokomocji), z drugiej jednak strony pozostawiały dość szeroki i dowolny zakres ewentualnej interpretacji (np. nieodpowiednie spotkania towarzyskie) $)^{8}$.

\section{Relacje z duchowieństwem}

I Synod wzywał do wzajemnej miłości w gronie kapłańskim, która jednak nie wykluczała w razie konieczności upomnienia braterskiego. Duchowni powinni byli także angażować się w działalność stowarzyszeń, bractw i wspólnot kapłańskich. W tym kontekście szczególnie przypomniany został obowiązek przynależności do Diecezjalnego Stowarzyszenia Wzajemnych Modłów o Śmierć Szczęśliwą. Kapłanowi nie wolno było obmawiać czy krytykować współbraci, a wobec każdego konfratra, nawet zupełnie nieznanego, miał zachować uprzejmość. Wszelkie kwestie sporne pomiędzy duchownymi miała rozstrzygać wyłącznie władza duchowna.

II Synod, jak również III Synod postulowały wzajemną miłość i ofiarne oddanie względem konfratrów. Apelowały także o obronę czci kapłańskiej, zakazując obmów i krytykanctwa (zwłaszcza w obecności wiernych świeckich). Położyły równocześnie nacisk na konieczność serdecznego upomnienia błądzących. Synody zobowiązały każdego kapłana do uczestnictwa w diecezjalnej organizacji wzajemnej pomocy Caritas Sacerdotalis. Ponadto przypomniały o celebrowaniu przynajmniej jednej mszy świętej za każdego zmarłego kapłana diecezji.

IV Synod przypomniał o zasadzie braterskiej życzliwości oraz współpracy pomiędzy księżmi diecezjalnymi i zakonnymi. Wyraźnie zostało też podkre-

8 R. Kantor, Synod w przededniu..., s. 99-100, 102-104, 148; KPK, s. 137; I Synod..., s. 66-70, 100; III Synod..., s. 349-355, 384-385; IV Synod..., s. 194-195, 245-246. 
ślone znaczenie „więzi braterskiej wśród duchowieństwa w jedności z biskupem”. Temu miały służyć m.in. odnawianie przyrzeczeń kapłańskich w Wielki Czwartek, wspólnotowe przeżywanie kolejnych rocznic święceń, kongregacje dekanalne połączone z modlitwą i pogłębianiem wiedzy teologicznej, wspólne odmawianie liturgii godzin, cotygodniowe spotkania duszpasterskiego zespołu parafialnego, przynależność do Unii Kapłańskiej, spotkania kapłańskie przy okazji odpustów parafialnych, imienin, kolędy, opłatków itp.

Szczególnym przejawem więzi braterskiej miała być relacja wobec starszych współbraci - kapłanów emerytów. Wspólnota kapłańska została zobowiązana do pomocy chorym konfratrom poprzez odwiedziny, niesienie pomocy duchowej, wyręczanie w obowiązkach duszpasterskich, ale też w dopilnowaniu uporządkowania kwestii materialnych i zabezpieczeniu intencji mszalnych (oczywiście na wypadek rychłego zgonu - ale nie zostało to wprost zapisane). Prawodawca synodalny przypomniał o ważnych zadaniach Caritas Sacerdotalis, która miała zapewnić pomoc każdemu kapłanowi w jego doczesnych lub duchowych potrzebach. Pośród tych zadań były także troska o świętość kapłańską i „rozwój wzajemnej uczynności”. Pamięć o zmarłych kapłanach miała się uzewnętrzniać w udziale w uroczystościach pogrzebowych, trosce o groby kapłańskie, ofiarowaniu mszy świętej za każdego zmarłego współbrata9.

\section{Mieszkanie}

Wszystkie dotychczasowe synody diecezji tarnowskiej zaskakująco mało miejsca poświęciły postanowieniom dotyczącym kapłańskiego lokum. Sprawy te potraktowano raczej drugoplanowo, prawdopodobnie dlatego, że kapłańskie mieszkania były po prostu mieszkaniami służbowymi. Prawodawca skoncentrował się jedynie na stosownym wystroju i urządzeniu mieszkań. I Synod nakazał, aby w urządzaniu mieszkania zachować prostotę i skromność oraz unikać wytworności czy okazałości. Następne dwa synody diecezji tarnowskiej zasadniczo potwierdziły te reguły.

IV Synod dokładnie powtórzył określenie I Synodu sprzed ponad pół wieku o „prostocie i skromności” w urządzaniu kapłańskiego mieszkania. Wydaje się więc zatem, iż pomimo upływu wielu dziesięcioleci mieszkania duchownych

9 R. Kantor, Synod w przededniu ..., dz. cyt., s. 100-101; I Synod..., s. 66-67; III Synod..., s. 351; IV Synod..., s. 192-194. 
nie uległy szczególnie istotnym zmianom, wymagającym nowych zaleceń czy też nowatorskich rozwiązań ${ }^{10}$.

\section{Odpoczynek i czas wolny}

Poszczególne synody diecezji tarnowskiej w miarę szczegółowo traktowały wszelkie kwestie, związane z zagospodarowaniem i odpowiednim wykorzystaniem przez duchownych czasu wolnego od zajęć duszpasterskich. I Synod w statucie 37 zabronił kapłanom palić publicznie tytoń, polować w pojedynkę lub z nagonką, grać hazardowo albo dla zysku, tańczyć, uczęszczać do szynków, barów, piwiarni i lokali śniadańkowych (ówczesna terminologia) oprócz restauracyj - ale dla słusznej przyczyny. Prawodawca zakazał też uczęszczania do teatrów, kin czy cyrków, jednakże dopuścił udział w przedstawieniach o treści religijnej, naukowej, przygotowanych z okazji uroczystości kościelnych bądź narodowych albo urządzanych na cele dobroczynne. Duchownym zostało zabronione wydawanie wystawnych przyjęć, urządzenie lub popieranie festynów, balów i innych zabaw, nawet w związku z działalnością charytatywną (przy tej okazji można łatwo zauważyć, iż obecna praktyka jest całkowicie odwrotna od dawnej - np. urządzanie licznych festynów parafialnych).

W statucie 39 bardzo obszernie potraktowano sprawy finansowe - zakazano duchownym zajmowania się handlem (nawet przez pośrednictwo innych osób), pożyczaniem pieniędzy lub poręczeniami pieniężnymi. Pozwolono wprawdzie na nabywanie obligacyj i akcyj, ale jedynie ,przedsiębiorstw i spółek uczciwych”. Nie zostało jednak uściślone, jakie podmioty można uznać za uczciwe, a jakich nie można.

II i III Synod powtórzyły wyżej wymienione reguły, zabroniły ponadto kapłanom uczęszczania do opery na nieodpowiednie widowiska (za wyjątkiem koncertów i przedstawień dzieł klasycznych), nie wspomniały jednak w ogóle o cyrkach. W dokumentach IV Synodu nie było natomiast wzmianek, dotyczących opery, teatru, cyrku, a nawet kina czy telewizji.

W kwestii urlopów I Synod dawał dziekanom prawo do zgody na tygodniowy wyjazd proboszcza lub wikariusza poza parafię, natomiast proboszczom prawo do udzielania wikariuszom trzydniowego urlopu, „w razie potrzeby”. II Synod

\footnotetext{
${ }^{10}$ R. Kantor, Synod w przededniu ..., dz. cyt., s. 102; I Synod ..., s. 68; III Synod..., s. 353; IV Synod ..., s. 190.
} 
oraz III Synod dały ponadto wikariuszom prawo do dwutygodniowego urlopu wypoczynkowego, z tym że termin urlopu miał zależeć od zdania proboszcza i zezwolenia ordynariusza. IV Synod dawał proboszczom możliwość miesięcznego urlopu w ciągu roku, po uzgodnieniu z Kurią Diecezjalną. Natomiast na jeden tydzień urlopu mógł zezwolić proboszczowi dziekan. Wikariuszom parafialnym synod dał prawo do miesięcznego urlopu w roku kalendarzowym, za potwierdzeniem terminu urlopu przez proboszcza i za zgodą Kurii Diecezjalnej, a ponadto prawo do jednego dnia wolnego w tygodniu - jednak tylko, „o ile to jest możliwe". Interpretacja tej możliwości należała do proboszcza, przez co prawo wikariusza do dnia wolnego było nieraz iluzoryczne.

W dokumentach IV Synodu znalazł się też zapis o wymaganej zgodzie Kurii Diecezjalnej na zakup pierwszego samochodu. Statut ten, całkowicie zrozumiały w realiach połowy lat $80 . \mathrm{XX}$ wieku, w obecnych czasach stał się anachronizmem - bez wątpienia brak własnego pojazdu jest sporym utrapieniem dla kapłana i dla wiernych korzystających z jego posługi duszpasterskiej - może zatem dzisiaj należałoby raczej uzyskiwać zgodę Kurii Diecezjalnej na nieposiadanie samochodu ${ }^{11}$.

\section{Podsumowanie}

Wszystkie dotychczasowe synody diecezji tarnowskiej podjęły i opracowały liczne kwestie dotyczące kapłańskiego dążenia do świętości i wszelkich związanym z tym aspektów codziennego życia księży. Warto w tym miejscu prześledzić, jak na przestrzeni ostatnich prawie dziewięćdziesięciu lat ulegała zmianie codzienność, jak ewoluowało podejście prawodawcy kościelnego do różnych zagadnień. $Z$ biegiem lat pojawiały się nowe wyzwania, problemy, zagrożenia i nadzieje, a odchodziły w przeszłość zagadnienia niegdyś jakże istotne. Obecnie nie ma już obowiązku tonsury, a stałe noszenie sutanny przez duchownych jest zjawiskiem niezbyt częstym. $Z$ różnych względów wyszły z powszechnego użycia i nie funkcjonują takie określenia jak np. lokale śniadańkowe czy służba plebańska. Zmieniło się społeczeństwo i w związku z tym nieodwracalnie zmienił się też kapłan, „z ludu wzięty” i przez ten lud czy społeczeństwo formowany od najmłodszych lat.

${ }^{11}$ R. Kantor, Synod w przededniu ..., dz. cyt., s. 103-104, 117; I Synod ..., s. 68-69, 76; III Synod..., s. 353, 363; IV Synod..., s. 182-183, 190. 
Z pewnością niektóre ze statutów synodalnych (nawet z ostatniego, IV Synodu) wywołują dziś konsternację, gdyż tak mocno się zdezaktualizowały i tak bardzo odstają od obecnej sytuacji. Pamiętać jednak należy, iż za kolejne pięćdziesiąt czy sto lat podobny osąd może spotkać obecne dokumenty - one też mogą zostać uznane za archaiczną ciekawostkę.

Postanowienia wszystkich dotychczasowych synodów tarnowskiej diecezji należy zatem odczytywać z pokorą - są niewątpliwym świadectwem epoki, ówczesnego życia, troski o dobro diecezji, duchownych i świeckich. Ze statutów synodalnych tchnie mocno autentyczna miłość do Pana Boga i do Kościoła, powszechnego i lokalnego. Postanowienia synodów nie są bezdusznym kodeksem czy jedynie pragmatycznym regulaminem skutecznego działania, lecz są to, pełne głębokiej troski prawodawcy, wskazówki do realizacji powołania do zbawienia - dla wszystkich diecezjan. Odczytując w taki sposób dokumenty dawnych synodów, bierzemy z nich wszystko to, co najlepsze, i równocześnie przenosimy w przyszłość. 